\title{
Book Review: Archaeologies of the Heart
}

By Kisha Supernant, Jane Eva Baxter, Natasha Lyons, and Sonya Atalay (editors). Springer International Publishing. 2020. ISBN: 978-3-030-36349-9 \$119.00 (Print)

Reviewed by Ashley Hampton, University of Montana

Kisha Supernant · Jane Eva Baxter Natasha Lyons · Sonya Atalay Editors

\section{Archaeologies of the Heart}

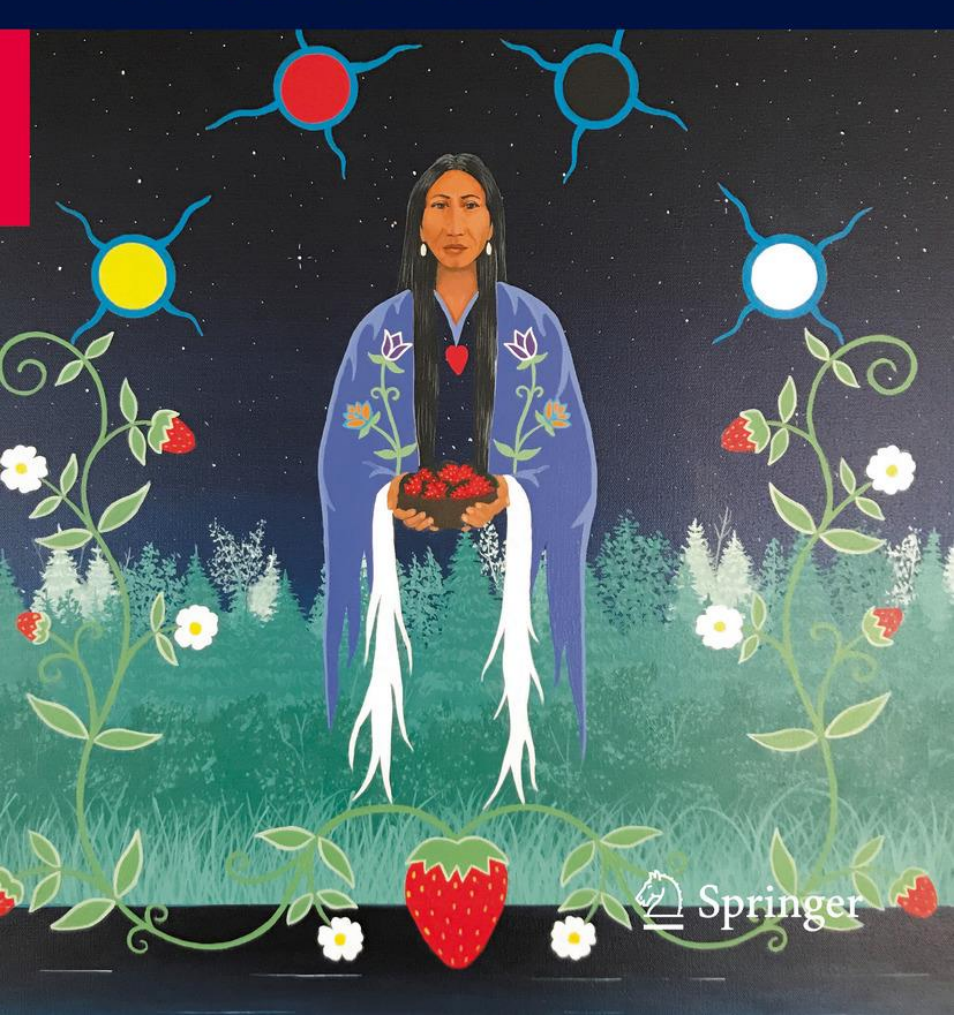

An archaeology of the heart, as championed within this volume, is an archaeology that recognizes different knowledge systems, understands the constraints of science, is multivocal, and begins with a self-reflexive and collaborative approach. To have an archaeology of the heart, we must reframe research away from the individual and to the collective, taking a critical approach to how we understand and create science, truth, and the past. Emerging from postprocessual reflexivity, this volume pushes for a new way of practice, a heart-centered practice, to archaeology and it does so with verdant joy. The volume introduces the work as a labor of love which is apparent on every page, as well as an appreciation for their collaborators, a gratitude to their communities of practice, and a love for what archaeology can be. The good that archaeology has and can do is the promise of a heart-centered approach and the promise of this volume.

The central premise, the weaving threads that bind all of these chapters together, is this sense of reframing archaeological practice around a heartcentered approach. This volume offers hope to future archaeologists, presenting an ambitious goal of injecting new perspectives, new methodologies, new appreciations, and new approaches into archaeology. It provides multiple examples of how heart-centered practice has and can be implemented in both theory and method - from Hodgetts and Kelvin's work on the Ikaahuk Archaeology Project to Surface-Evans operationalization of

Hampton, Ashley (2021) Review of Archaeologies of the Heart, by Kisha Supernant, Jane Eva Baxter, Natasha Lyons, and Sonya Atalay (editors). New Florida Journal of Anthropology, 1(2), 5-7 DOI: $\underline{10.32473 / \text { nfja.v1i2.126178 }}$ 
an epistemology of the heart in the archaeology program at CMU, from Rizvi's participatory practice to Abbott's entangled sociality of lithics - all of these chapters posit unique, purposeful insight into a new way of practicing archaeology. It would be easy to simply discuss the failings of archaeology, but instead this volume focuses on building from the ground up transformative practices in the hopes of making a difference. The contributors are all planting seeds in a new garden, building trellises of positionality and self-reflexivity, in the hopes that future academics may partake of this fruit and plant new beginnings themselves.

The volume is divided into two parts, "Heart-Centered Guidance for Practice and Engagement" and "Heart-Centered Encounters with the Archaeological Record". The first six chapters on practice and engagement provide multiple, practical examples of how archaeologies of the heart have been implemented, sometimes unwittingly and other times purposefully. These chapters are vital links for new academics to understand how to go beyond a theory, beyond a desire to change, and provide ways to actually practice the heart-centered approach. In particular, the discussion by Hoffmann is especially illuminating because it traces their own personal path, cultivated through personal experience, to becoming the humble archaeologist.

The last six chapters highlight the relational theme between self and the material record. A central piece of all of these chapters is the crafting and acknowledgement of a personal connection with the past. As practitioners of archaeology, the unique power we hold, the capability to upend our understanding of the past through the work that we do, can often be forgotten. This second half brings the emotional capacity of archaeology to the forefront, highlighting the personal relationships we forge with the past and allowing those feelings room to breathe and room to change us. For instance, Gelder accomplishes this through a meaningful depiction of the relational landscape possibilities derived from examinations of Upper Paleolithic cave painting.

More general themes for the work include ethics of care, relationality, and community-driven archaeology. This recognition that emotion can guide our discipline into a new harbor, that our emotions as practitioners of the past are not detrimental qualities to be disregarded, is a refreshing recognition that scientists are human. The idea that emotion can be a source of strength, a source of learning and a source of healing, is important to reconciling the impact of archaeological work on descendent communities and the self. This is seen in the self-reflective approach in such chapters as Rizvi's frank discussion on research relationships and Hoffmann, Hodgetts, and Kelvin's consideration of their work with Indigenous communities. Authorial analysis of the motivations for practicewhy they are archaeologists, why they were drawn to the discipline, and what being an archaeologist means to them-is also prominent in multiple chapters, connecting to the overall self-reflective nature of the volume. It is clear that an understanding of personal motivations is central to self-positionality and forms a vital branch of the heart-centered approach. Acknowledging an indebtedness to Anderson's Ecologies of the Heart, this volume showcases how to productively employ reflexive scientific analysis in the social sciences.

An ethic of care forms another prevalent theme, promoting ways archaeologists may bring the whole self into practices of interpretation and how this strengthens the 
interpretative process. By consciously bringing our hearts into the labor of science, we take responsibility for the full breadth of what archaeology can mean to the wider community. Again, tying back to the self-reflective roots, the heart-centered approach to archaeology acknowledges that stories of the past are not produced out of, or into, a vacuum, and by appreciating this factor the volume posits we may begin to craft a more authentic practice. The role of feminist and Indigenous theory in restructuring the archaeological discipline is made plain, with the conceptual model of the Indigenous research paradigm and Indigenous research concepts being especially important. Calls for change have been prominent and the need to address the ethical pitfalls in our discipline is long overdue. The transformative power of the epistemology of the heart, as presented, offers the promise of a new way forward towards a discipline-wide ethic of care and respect.

The symbolism of the heart berry (or wild strawberry), the importance of relationality, connection, entanglement, and the transformative power of archaeology, is encapsulated by Atalay's closing chapter. Atalay recounts two stories, the Haudenosaunee Sky Woman story and the Anishinaabe "Earth Diver" story of life after the great flood, and the lessons these stories hold. Through discussing how these stories are reflected in different ways throughout the chapters of this volume, Atalay posits that it is through "stories a path forward for archaeology" may be achieved (255). This is a powerful reminder and a poignant one. Ultimately this volume is a significant contribution and an extraordinary gift to the field and beyond because it provides a promising way forward for crafting a new kind of archaeology -an archaeology of the heart.

Hampton, Ashley (2021) Review of Archaeologies of the Heart, by Kisha Supernant, Jane Eva Baxter, Natasha Lyons, and Sonya Atalay (editors). New Florida Journal of Anthropology, 1(2), 5-7 DOI: $\underline{10.32473 / \text { nfja.v1i2.126178 }}$ 